\title{
The Distinction between Public Law and Private Law
}

The separation of administrative courts from the ordinary civil and criminal courts is a constitutional principle in France. In the Competition Law decision of 1987 , the Conseil constitutionnel ruled: ${ }^{1}$

Considering that the provisions of articles 10 and 13 of the Law of 16 and 24 August 1790 and of the decree of 16 Fructidor Year III, which laid down in general terms the principle of the separation of administrative and ordinary judicial authorities, do not, in themselves, have constitutional value; as, nevertheless, consistent with the French conception of powers, there figure among the 'fundamental principles recognised by the laws of the Republic' one by which, except for matters reserved by their nature to the ordinary courts, there belong to the administrative courts in final instance the nullity or rectification of decisions taken in the exercise of the prerogatives of public power by authorities exercising executive power, their agents, local authorities or, public bodies placed under their authority or control.

France is unusual in considering that the separation of administrative and ordinary courts is a constitutional requirement, rather than just a matter of tradition or administrative convenience. In other European countries such as Germany and Italy, separate administrative courts are staffed by members of a common judiciary. ${ }^{2}$ In Spain, England and Wales and Scotland, the

1 CC decision no. 86-224 DC of 23 January 1987, Competition Law, Rec. 8, para. 15. The reason the Conseil constitutionnel had to reject the key texts it mentions as a basis for its decision was that the first was a law of a monarchy and the second was a mere decree, as was the decree of 31 July 1945, which then set out the current rules on the Conseil d'Etat. Implicitly, the decision relied on the Law of 24 May 1872 on which its decision on the independence of administrative judges had already relied: CC decision no. 80-119 DC of 22 July 1980, Validation of Administrative Decisions, Rec. 46.

2 J. Bell, Judiciaries in Europe (Cambridge: Cambridge University Press, 2005), chapter 3, sections 2 and 3 . 
administrative courts are merely a division of the common court system. ${ }^{3}$ To have distinct administrative courts with their own distinct judiciary is unusual in Europe. France is unique in having this distinctiveness entrenched as a constitutional requirement.

The French position is a clear example of path dependency. The requirement that the ordinary courts should not seek to review administrative decisions was already laid down by the edict of St Germain-en-Laye of February 1641, which prohibited the Parlements from being concerned with litigation 'concerning the State, administration or government which we reserve to ourselves alone and to our successor kings'. This arose out of conflicts in the recently unified French state between the king and the aristocrats who were the judges in the Parlements. A similar wariness of those ordinary court judges was reflected in the early legislation of the Revolution. The Law of 16 and 24 August 1790 provided that the judicial functions are distinct and shall always remain distinct from administrative functions; judges may not, on pain of forfeiture of office, interfere in any manner whatsoever with the activities of administrative bodies nor summon before them administrators for reasons of their office' (art. 13). ${ }^{4}$

This antagonism between the ordinary judiciary and the administration no longer provides a justification for the separation of ordinary and administrative courts. So French jurists of the past 150 years have sought to rationalise and justify the continued distinction. The declaration by the Conseil constitutionnel in 1987 illustrates that process of reinterpretation. Although many authors have tried to propose one, it will be seen in Section 5 that there is no single criterion by which the distinction is made adequately. The declaration of the Conseil constitutionnel offers three dimensions which can usefully serve as a framework for our consideration of the question: (1) the subject matter of any decision before the court ('the nullity or rectification of decisions') discussed in Sections 1 and 2; (2) the body that took those decisions ('authorities exercising executive power, their agents, local authorities or, public bodies placed under their authority or control') discussed in Section 4; and (3) the nature of the administrative decision challenged before the court ('decisions taken in the exercise of the prerogatives of public power') discussed in Section 5. The Conseil constitutionnel decision did not need to mention that actions of the administration which constitute a flagrant illegality (the so-called voie de fait) fall within the jurisdiction of the ordinary courts. This will be discussed in

3 Ibid., chapter 4, section 3 .

4 For a useful short summary of the history, see M. Guyomar and B. Seiller, Contentieux administratif, 5th ed. (Paris: Dalloz, 2019), nos. 13-28. 
Section 3. Apart from this competence set out by the Conseil constitutionnel in order to safeguard a minimum jurisdiction to administrative courts from encroachment by the legislator, it is for the ordinary courts and their supreme courts (Conseil d'Etat, Cour de cassation and where conflicts arise, the Tribunal des Conflits) to interpret the legislative principle of the separation of administrative and ordinary judicial authorities and decide on the criteria which illustrate it. Each area of administrative has its own criteria (administrative contracts, unilateral administrative act, public works, public agent, domaine public etc.) laid down by the case law, but there is often either simply a reference of prerogative of public power (prérogatives de puissance publique) or of public service (service public) or to both. Indeed, the question of which criterion should prevail opposed at the beginning of the twentieth century two deans who were also professors of public law (and their followers): the dean of Toulouse Maurice Hauriou, who claimed the jurisdiction of administrative courts should be limited to the use of prerogative of public powers, whereas the dean of Bordeaux Léon Duguit took the view that it should extend to any public service mission - that is, every time the administration acted in the general interest. Although the case law did not decide in favour of one or another theory, this distinction remains a landmark in the case law when constitutional competence is not at stake.

\subsection{THE SUBJECT MATTER OF LITIGATION AT THE CONSTITUTIONAL LEVEL}

The Conseil constitutionnel decision focuses on the issue of the legality of administrative decisions as the core of the distinctive competence of the administrative courts at the constitutional level. This, indeed, was the most obvious way in which the ordinary courts could interfere with the administration. But, as Laferrière noted in 1887 , actions for damages against the administration could impose burdens on the public treasury and thereby impede the work of the administration. ${ }^{5}$ So it is necessary to consider not only judicial review, but also actions relating to contracts, compensation and property.

\subsubsection{Illegality}

The legality of administrative decisions involves the analysis of whether there is a legal source of authority for the decision, and whether the bounds of the

5 E. Laferrière, Traité de la juridiction administrative et des recours contentieux, 1st ed. (Paris: Berger-Levrault, 1887), p. 13. 
legal authority have been respected. It is here that an understanding of both the body of law relating to the administration and the way the administration works is valuable in coming to a ruling on whether the administration has acted lawfully.

The issue of the legality of an administrative decision arises most straightforwardly when the claimant seeks to annul an administrative decision affecting her. The procedures for bringing such an action are only found in the Code de Justice Administrative (CJA), and they can only be brought in the administrative courts. Indeed, in Entry and Residence of Foreigners in 1989, the Conseil constitutionnel went so far as to strike down a law which transferred competence over the administrative expulsion of foreigners to the ordinary courts. ${ }^{6}$

\subsubsection{Exceptions to the Separation of Administrative and Ordinary Judicial Authorities}

There are a number of exceptions to the principle that it is for the administrative courts to rule on the legality of administrative decisions. The Conseil constitutionnel decision of 1987 refers to 'matters reserved by their nature to the ordinary courts' and, in addition, the decision permitted legislation to make exceptions 'in the interests of the good administration of justice'.

\subsubsection{The Defence of Illegality before the Civil Courts}

The legality of an administrative decision may arise not as the ground of action, but as a defence. At this point, the court hearing the case has to determine whether it is competent to adjudicate on the matter, or whether this particular issue needs to be referred for decision by the administrative courts. The principle was laid down by the Tribunal des Conflits in Septfonds. ${ }^{8}$ In this case, a merchant sent forty-three bags of sugar by train, and they were lost. The merchant sued the (private) railway company before the commercial courts for breach of contract. A ministerial order made under war powers set a short time limit for bringing such claims. The prefect objected that the court was not competent to interpret this order. The Tribunal des Conflits held that the order was an administrative decision which was legislative in character, since it applied to all rail freight contracts.

6 CC decision no. 89-261 DC of 28 July 1989, RFDA 1989, 691 note Genevois.

CC decision no. 86-224 DC of 23 January 1987, Rec. 8, para. 16.

TC 16 June 1923, Septfonds, no. 00732, S. 1923.3.49 note Hauriou. 
The legality of the order could be decided only by the administrative courts. But the ordinary courts were competent to interpret its meaning when applying the legislation in question when there was a contested issue of interpretation during the course of litigation properly brought before them. Interpretation is part of the process of application, rather than challenging the validity of the order. But since the Septfonds case, the Tribunal des Conflits introduced four exceptions to the duty of civil courts to send a preliminary question to administrative courts: when they have to assess the legality of an administrative regulation which constitutes a voie de fait ${ }^{9}$ and when tax law is at stake. ${ }^{10}$ Two other exceptions can be claimed as a consequence of the good administration of justice (see Section 2.4).

Two possible solutions could be applied to this situation. The first is to apply the maxim 'the judge of the action is the judge of the defence' (le juge de l'action est juge de l'exception). This would breach the principle of the separation of courts, but would be efficient from the point of view of litigants. Alternatively, the civil court seised of the case would have to suspend proceedings in order to send a preliminary question (question préjudicielle) to the administrative court for a ruling. Both of these alternative solutions are reflected in art. 49 of the Code of Civil Procedure, which provides that the civil courts are competent to decide all issues raised by way of defence except those which belong to the exclusive jurisdiction of another court - for example, the administrative courts. Where a serious question is raised falling within the jurisdiction of the administrative courts, the civil court must submit the question to the relevant administrative court. But the administrative court is restricted to answering the preliminary question put to it by the civil court. An example is where a purchaser of land sought to have the contract annulled when she discovered that the local mayor claimed one of the property's walls was public property. The cour d'appel submitted to the tribunal administratif the question of whether the wall separating the property from the road was public property. The Conseil d'Etat ruled that it was public property. ${ }^{11}$ But it also ruled that the lower tribunal administratif to which the case was originally referred was wrong to answer a separate question - namely, whether the repair of the wall was a public work for which the mayor could claim a contribution from the landowner. Similarly, art. R771-2 CJA provides that where litigation in an administrative court raises a serious question lying within the

9 TC 20 October 1947, Barinstein, Leb. 511.

10 TC 7 December 1998, District urbain de l'agglomération rennaise c Société des automobiles Citroën, no. 03123, D. 1999, 179, concl. Sainte-Rose.

11 CE 23 January 2012, no. 334360. 
jurisdiction of the ordinary courts, the court should suspend proceedings and refer the relevant question for a ruling by the civil court.

\subsubsection{Criminal Proceedings}

The need for justice to be speedy is important when criminal penalties are at stake. Criminal courts may always determine the legality of administrative decisions. The principle was affirmed in Avranches et Desmarets: ${ }^{12}$

It follows from the nature of the mission assigned to the criminal court that it has, in principle, full competence over all issues on which the imposition or non-imposition of penalties depends; as it may, for this purpose, not only interpret ... administrative regulations, but also assess their legality when they serve as the basis for a prosecution or are invoked as a ground of defence.

In this case, the son and son-in-law of a tenant were prosecuted for poaching on neighbouring land. Their defence was that a standard clause in the tenant's lease inserted by order approved by the prefect of the département permitted such hunting. The criminal court declared the clause illegal as, in its view, the parent legislation only allowed such a clause to permit hunting on the land leased, but not more widely. The prefect raised the objection that the legality of an administrative rule should be decided by the administrative courts, but the Tribunal des Conflits rejected this objection and upheld the right of the criminal court to decide the matter. However, the Avranches et Desmarets case implicitly made an exception to the competence of criminal courts for the assessment of legality of individual administrative decisions.

The principal solution the Tribunal des Conflits adopted is now contained in art. 111-5 of the Penal Code of 1992, which no longer provides for any exception:

Criminal courts have competence to interpret administrative decisions, whether regulatory or individual, and to determine their legality when the outcome of the criminal case submitted to them depends on such a determination.

This entails that the criminal court is bound to rule on any defence. Thus, the cour d'appel of Pau was wrong to deny its competence to consider a defence which alleged that the decree under which a company was prosecuted was unconstitutional. ${ }^{13}$ In the case, the company sold foie gras containing

12 TC 5 July 1951, no. 01187 , S. 1952.3.1 note Auby.

13 Crim. 29 January 2019, no. 17-84366, D. $2019,257$. 
reconstituted by-products of the deveining process. The defendants alleged that the decree breached the principle of equality before the law in requiring national products to meet standards different from those that were lawful in other Member States of the European Union (EU). Because this affected whether their actions were unlawful, the criminal court was bound to determine the matter. Article 111-5 of the Penal Code also empowers the criminal judge to rule on the legality of searches authorised during a criminal investigation. ${ }^{14}$

\subsubsection{Protection of Civil Liberties and Private Property}

Article 66 of the Constitution provides that the ordinary judge is 'guardian of individual liberty'. In particular, that article focuses on preventing arbitrary detention, but this traditional competence also covers personal status and interference with property. As the Tribunal des Conflits put it, there is a general principle that the protection of individual liberty and the protection of private property belong essentially to the attributes of the ordinary courts'. ${ }^{15}$

The issues related to personal status cover civil status (name, paternity, marriage), legal capacity and nationality, as well as qualification as an elector. There are some exceptions, most notably the change of name which, under arts. 60 to $61-4$ of the Civil Code is determined by the Conseil d'Etat in its administrative capacity. Decrees of naturalisation are also within the domain of the administrative courts.

The scope of 'the protection of individual liberty' has been the subject of substantial litigation before the Conseil constitutionnel. ${ }^{16}$ The core is the role of the criminal judge controlling the detention of individuals before trial and imprisoning them after conviction. In this work, the judge (often the procureur or the juge d'instruction) is assisted by the judicial police (police judiciaire). Article 136 of the Code of Criminal Procedure provides that in all cases of an interference with individual freedom, the administrative authorities may never raise a conflict and the ordinary courts always have exclusive competence'. But the Tribunal des Conflits has held that this does not give competence to the ordinary courts to rule on the legality of the decision on the basis of which the administration is interfering with an individual's liberty. ${ }^{17}$ It held

14 Crim. 13 December 2016, no. 16-84794, D. 2017, 275 note Pradel.

15 TC 18 December 1947, Hilaire, no. 00976 , D. 1948, 62.

16 For a survey, see G. Eveillard, 'Les matières réservées par nature à l'autorité judiciaire', AJDA 2017, 101, esp. pp. 106-11.

17 TC 12 May 1997, Préfet de police de Paris c Tribunal de grande instance de Paris, no. 03056, RFDA 1997, 514 concl. Arrighi de Casanova. 
in that case that the ordinary court could not consider the legality of the order made by the prefect in relation to Moroccan migrants neither to enter French territory nor to leave the ship on which they had arrived in France.

On the one hand, the Conseil constitutionnel has held that a number of restrictions on the individual do not constitute infringements of individual liberty within the meaning of art. 66 of the Constitution. Administrative decisions authorising tax or customs searches, ${ }^{18}$ restricting a person to their residence ${ }^{19}$ or stopping and searching vehicles ${ }^{20}$ are not considered within its scope, nor are detention of seriously mentally ill people ${ }^{21}$ and holding illegal migrants in waiting areas. Indeed, in Entry and Residence of Foreigners in 1989, the Conseil constitutionnel went so far as to strike down a law which transferred competence over this administrative expulsion of foreigners to the ordinary courts. ${ }^{22}$ That decision limits 'liberty of the individual' to detention, criminal penalties and civil status. But where the detention has to be extended because the immigrant could not be expelled immediately, then the ordinary courts have competence to determine the terms under which the person is held. ${ }^{23}$

On the other hand, France has been aware of the requirements of the European Convention on Human Rights to provide adequate protection against detention. ${ }^{24}$ Created by a law of 2000 , the juge des libertés et de la détention has jurisdiction over a wide range of interferences by the state into individual liberty. In such situations, the judge authorises detention, rather than just reviewing the legality of actions by the police or the administration. In this way, the separation of powers is respected, but the role of the ordinary judge as the protector of civil liberties is enhanced. In criminal matters, under art. 137-1 of the Code of Criminal Procedure, the judge deals with preventive detention during the investigation of a criminal offence, as well as authorising searches and telephone or electronic surveillance. Since 2011, the judge has had jurisdiction concerning the detention of the mentally ill (Public Health Code, arts. $\mathrm{R}_{3211-10}$ and following), and of migrants rejected entry into France and detained beyond a short period of forty-eight hours (Code on the Entry and Residence of Foreigners and Asylum, art. L552-1). The judge is also

18

19

20

21

22

23

24 
responsible since 2017 for administrative visits to homes as part of antiterrorism legislation. Effectively, this judge has become a major person responsible for protecting liberty, thereby limiting the role of the administrative courts. Although the role is not to review the legality of administrative decisions, it has a major impact by transferring competence to make decisions away from the administration and giving it to a civil judge.

In relation to interference with property rights, the Conseil constitutionnel has recognised a general principle of law that competence in such matters lies with the ordinary judges. In TGV Nord, a law allowed the administration to expedite the expropriation process for the construction of a TGV line by taking possession of the property by a decree after a favourable opinion of the Conseil d'Etat. ${ }^{25}$ The normal procedure for an expropriation order had then to be begun before the civil judge within a month for fixing the amount of compensation. The Conseil did not disapprove of this but set out a new principle:

as, thus, in any case, the importance of the functions conferred on the judicial authority in relation to immovable property by the fundamental principles recognised by the laws of the Republic is not disregarded.

Commentators have some difficulty in discerning which laws of the Republic are referred to, but it seems clear from this that the traditional functions of the judiciary in expropriation of immovable property are to be treated as of constitutional value. The competence of an ordinary judge to order the transfer of property and to determine the compensation for expropriation had been settled since a Law of 8 March 1810 (a Law of an Empire). Numerous laws since then have given the determination of compensation for decisions on matters such as requisitioning private property. In the case of administrative servitudes over private property, some laws have given jurisdiction to the ordinary judges, but in the Eiffel Tower Amendment decision, the Conseil had held further that 'no principle of constitutional value requires, in the absence of dispossession, that compensation for harm caused lies within the jurisdiction of the civil judge'. ${ }^{26}$ In that case, the Law permitted Télédiffusion de France to install and use equipment for transmitting radio and television programmes on roofs, terraces, and the superstructure of buildings. The building principally envisaged was the Eiffel Tower, owned by the City of Paris. The installation had to be approved by the president of a tribunal de grande instance. The Conseil took the view that creating an administrative

25 CC decision no. 89-256 DC of 25 July 1989, TGV Nord, RFDA 1989, 1009 note Bon. Local farmers were selling off their land in very small units in order to make the expropriation process more difficult.

26 CC decision no. 85-198 DC of 13 December 1985, D. 1986, 345 note Luchaire. 
easement of this kind did not amount to the deprival of a property right. The conclusion would have been different, it continued, if the effect of the easement had been to empty the property right of all content or had affected persons occupying the property.

\subsubsection{The Good Administration of Justice}

The good administration of justice is a recognised constitutional objective. ${ }^{27}$ In addition, as seen earlier, general principles of law establish that a litigant has a right to a decision within a reasonable time, a principle influenced by the European Convention on Human Rights. ${ }^{28}$ The Tribunal des Conflits has used these values to add flexibility to the allocation of competences set out in Septfonds. In joined cases INAPORC and CNIEL, it decided that a civil court need not transmit a preliminary question where it appears clearly, on the basis of established case law, that the matter can be resolved by the civil court. ${ }^{29}$ This is a French version of the acte clair doctrine in EU law. ${ }^{\circ}$ The Tribunal des Conflits also held in that case that, in order to ensure an effective remedy as required by EU law, the civil court could refer a preliminary question to the Court of Justice of the European Union (CJEU) without first referring the case to the administrative courts. In this case, the question at issue was the validity of compulsory contributions to inter-professional associations in the light of EU rules on state aid. This more flexible approach was picked up by the Conseil d'Etat in Fédération Sud Santé Sociaux and represents a focus on the value of expertise in other courts being used when needed, rather than a more doctrinaire distinction between public and private law. ${ }^{31}$ In that case, it ruled that, where the good administration of justice and, in particular, the right of litigants to a judicial decision within a reasonable time so require, the court initially seised of the case may rule on all the matters involved in the case. In that specific case, the private law issue was a novel and complex matter concerning collective agreements and so the issue was referred to the private law courts for an opinion. Overall, it would appear that courts on either side of the divide may be willing to rule on relatively settled issues of law from the

27 CC decision no. 2006-545 DC of 28 December 2006, Rec. 138.

28 See Chapter 4, Section 1.4.

29 TC 17 October 2011, SCEA de Chéneau v Interprofessional nationale porcine (INAPORC) and Centre national interprofessionnel de l'économie laitière (CNIEL), no $\mathrm{C}_{3} 828$, RFDA 2012,122 concl. Sarcelet, note Seiller.

30 The phrase used by the Tribunal des Conflits - 'well established case law' - is the same as that of Protocol 14 to the European Convention on Human Rights, which came into force in the previous year and justified remitting cases to smaller panels of judges.

31 CE 23 March 2012, Fédération Sud Santé Sociaux, no. 331805, Leb. 102. 
other branch of the law in order to ensure a speedy resolution of a dispute on which the court is otherwise competent. But references will be made on complex issues, as will be explained further in Section 7.3.

\subsubsection{Legislative Exceptions}

The Conseil constitutionnel in 1987 made clear that

Where the application of specific legislation or regulation could give rise to a variety of litigation which would be distributed according to the normal rules on competence between the administrative courts and the ordinary courts, it is lawful for the legislator, in the interests of the good administration of justice to unify the rules of judicial competence within the judicial body principally affected. ${ }^{32}$

Thus, in that case, on the application of the normal rules on competence, litigation on competition could arise before administrative courts, criminal courts and commercial courts. So it was permissible for the legislator to bring all the competition litigation into the ordinary courts and give the Cour de cassation the role of ensuring a unified interpretation of the legal rules.

This approach has been followed in relation to other economic legislation. So the cour d'appel of Paris, acting exceptionally as a court of first instance, has been given jurisdiction to examine the decisions of the Financial Markets Authority (the Autorité des marchés financiers), the authority regulating electronic communications and La Poste, and the commission regulating energy. ${ }^{33}$

\subsection{OTHER CATEGORIES OF LITIGATION}

Apart from questions of legality dealt with by the constitutional principle, the administrative courts have jurisdiction over other types of litigation concerning the administration, especially contracts and commercial activities, public property and the liability of public bodies. But this jurisdiction is concerned with the interpretation of the principle of the separation of administrative and ordinary judicial authorities, not with the fundamental principle recognised by the laws of the Republic quoted earlier in this chapter and discovered in 1987 by the Conseil constitutionnel.

32 CC no. 86-224 DC, note 1, para. 16.

33 See M. Lombard, G. Dumont and J. Sirinelli, Contentieux administratif, 13th ed. (Paris: Dalloz, 2019), no. 663 . 


\subsubsection{Contracts and Commercial Activities}

As will be seen in Chapter 9, there is a substantial body of law relating to administrative contracts which fall within the jurisdiction of the administrative courts. Unlike classic administrative decisions, contracts made by the administration do not impose obligations on another, but are the result of agreement in which the other party may be in a stronger bargaining position. The Proposal for a Regulation on a Common European Sales law did not differentiate between public and private contracts, except to exclude contracts in the exercise of public authority (such as rights of pre-emption under legislative authority). ${ }^{34}$ French law, on the other hand, adheres to its differentiation between public contract law governed by public law rules and adjudicated by the administrative courts and private contract law governed by private law and adjudicated by the ordinary courts. It therefore becomes important that contracting parties know which is the relevant governing law.

In very broad terms, a French administration can enter into both administrative contracts (contrats administratifs) and private law contracts (contrats de droit privé). The two traditional criteria for identifying the former are that the administrative contract relates to a public service and that it reserves exceptional powers to the administration (it contains clauses exorbitantes du droit commun). Either criterion may suffice to make a contract 'administrative' in character, but the involvement of the contract in the provision of a public service is the primary criterion. The classic example is Terrier, discussed in Section 5 , in which an advert made to the public offering a reward for catching vipers was held to be a public contract. ${ }^{35} \mathrm{~A}$ further example would be that a contract with a constructor to build a school is a public contract because it is a way of providing a public service or education. But a contract with a dairy to provide milk for the school canteen would be private, since it is merely about supplies, rather than the actual provision of the public service. Despite their apparent simplicity, these criteria give rise to a complex case law which will be explained more fully in Chapter 9.

\subsubsection{Property}

Just as public bodies may make either public or private contracts, depending on the issue in question, so public bodies (like the Queen in England) may have a public and a private domain. Article L2111-1 of the General Code on the

\footnotetext{
$\mathrm{COM} / 2011 / 0635$ final.

35 CE 6 February 1903, Terrier, no. 07496, Leb. 94, D. 1904.3.65 concl. Romieu.
} 
Property of Public Persons provides that property belonging to a public person (as listed in art. Li of the Code) is public domain if it is dedicated to use by the public or in a public service, provided it has been adapted in a way indispensable to performing the public service. An example of the former is a public park. An example of the latter might be a garage specially designed for public service buses. Movable property may be included - for example, art or archaeological objects. Special rules govern the disposal of public property and the administrative courts have jurisdiction to determine disputes on such matters.

Since the Law of 28 pluviôse An VIII, special rules govern public works such as canals or roads. As has been seen, the status of something as a public work is a matter for the administrative courts. ${ }^{36}$ Interferences with public works are also a disciplinary matter for the administrative courts, imposing fines for such acts (the contentieux de la répression).

\subsubsection{Liability of Public Bodies}

Chapter 8 will explain that there are special rules on the liability of public authorities. These special rules of liability are applied by the administrative courts. The Tribunal des Conflits made the point in Blanco in 1873 that ${ }^{37}$

the liability which may be incurred by the state for the loss caused to individuals by the actions of persons whom it employs in the public service cannot be governed by the principles laid down in the Civil Code to regulate the legal relationships of individuals.

The consequence of separate rules was a separate jurisdiction to administer them. As will be seen in Chapter 8, these rules govern both fault-based and nofault liability. All the same, for the good administration of justice, Parliament has legislated to group litigation on certain matters within the ordinary courts, even when they relate to public law activities.

Among the earliest areas was accidents at work. Compensation for such accidents was introduced in 1898 and it provided that litigation on the matter would belong in the ordinary courts, whether the employer was a public or a private body. This enabled a coherent development of the law relating to a substantial number of physical injuries.

36 CE 23 January 2012, no. 334360 , note 9.

37 TC 8 February 1873, Blanco no. 00012, D. 1873.3.17, translated by D. Fairgrieve, State Liability in Tort. A Comparative Law Study (Oxford: Oxford University Press, 2003), p. 288. 
This approach was extended to motor vehicle accidents by the Law of ${ }_{31}$ December 1957. It made little sense for separate rules to govern the victim's injuries depending on whether she was knocked over by the mayor's official car driven on official business or by his personal car driven on a personal errand. The same arrangement has carried over into the compensation arrangements under the no-fault scheme established in 1985 .

Harm arising from nuclear accidents was reserved by the Law of 1968 to the civil courts. The special compensation scheme for acts of terrorism introduced in 1986 gives litigation competence to the civil courts. In 1991, the cour d'appel of Paris was similarly given jurisdiction over litigation against decisions of the compensation commission set up to deal with AIDS-infected blood. This was necessary because blood transfusion might be conducted by public or private institutions.

\subsection{VOIE DE FAIT}

Voie de fait (literally an 'assault' or perhaps better a trespass) identifies a flagrant illegality and is not so much an exception to the rules on the jurisdiction of the administrative courts as the point where the justification of distinct treatment for the administration runs out.

Where the administration interferes seriously and unlawfully with individual freedoms or property, then the individual affected can challenge the legality of the action before the administrative court, especially using the référé-liberté procedure discussed in Chapter 4, Section 3. But where the action is flagrantly illegal, the administration is considered to have departed so far from its functions that its action is considered a mere fact lacking any legal justification at all. The action has lost all its administrative character and does not merit any special treatment, so it falls within the jurisdiction of the ordinary courts, civil or criminal.

A voie de fait involves a physical operation and a flagrant legal defect affecting the freedom of the individual or the extinction of a property right. The requirement of a physical operation involves not just the making of a decision, but also its implementation or the threat of its implementation. That implementation must interfere with the rights of an individual. In its decision in Bergoend, the Tribunal des Conflits held that ${ }^{3^{8}}$

there is no voie de fait on the part of the administration justifying, as an exception to the separation of the administrative and judicial authorities, the

$3^{8}$ TC 17 June 2013, Bergoend c Société ERDF Annecy Léman, no. C3911, RFDA 2013, 1041 note Delvolvé. 
courts of the ordinary judiciary to order it to cease or to be compensated unless either the administration has proceeded to the use of force in unlawful circumstances to implement a decision, though lawful, which interferes with freedom of the individual or leading to the extinction of a property right, or has taken a decision which has the same effects on the freedom of the individual or the extinction of a property right and is flagrantly incapable of being related to a power belonging to an administrative authority.

This restricted voie de fait to the unlawful use of force or to implementing a decision which is not just unlawful, but also is flagrantly not something the administration could claim to do. In that case, the company in charge of the electricity grid erected a pylon in 1983 on the claimant's land without following the requisite procedures to obtain authority to do so. In 2009, the claimant brought an action before the civil courts to order its removal. The action did not extinguish a property right, because it was a mere servitude, and it was not flagrantly something the administrative body could not do, because EDF (by then ERDF) had statutory power to erect pylons on private land.

The decision continued the long-standing case law that identifies two types of flagrant illegality: the unlawful use of force to implement a lawful decision affecting the freedom of the individual or a property right, and the making of a flagrantly unlawful decision to the same effect. But it did restrict the interference with property to where the property right is extinguished, not just where it is interfered with, as previous case law had done. ${ }^{39}$ The Tribunal des Conflits confirmed this in another decision of 2013 , Panizzon. ${ }^{4 \circ}$ In that case, a commune contracted to use adjoining land as part of its sports facility. At the end of the contract term, it did not return the land. The landowners brought an action for the return of the land before the civil courts. Because this was not a total extinction of their title (indeed the commune was trying to buy the land from them), the Tribunal des Conflits held that the civil court was wrong to claim jurisdiction over the matter.

In Bergoend, the Tribunal des Conflits also restricted voie de fait to 'freedom of the individual', not to other rights, and in this it brought this exception into line with the scope of art. 66 of the Constitution discussed in Section 1.2.3. In the past, leading cases of voie de fait had included flagrantly unlawful interference with the freedom of the press $^{41}$ or the withdrawal of a passport from an

39 For example, the unlawful taking possession of an individual's property: TC 24 June 1954, Société Trystram, no. o1434, Leb. 716.

$4^{\circ} \quad$ TC 9 December 2013, Panizzon c Commune de Saint-Palais-sur-Mer, no. C3931, Leb. 376. The Cour de cassation has aligned itself to this position: Cass. 3 civ., 11 March 2015, Société de l'Avenir, no. 13-24133, AJDA 2015, 1301.

${ }^{41} \quad$ TC 8 April 1935, Action française, no. o0822, S. 1935.3.76 concl. Josse. 
individual who owed large sums in taxes and appeared not to be sufficiently solvent to pay them. ${ }^{42}$ Now, the mere retaining of a foreigner's identity papers longer than necessary to check their validity does not constitute a voie de fait, even if it is a restriction on the freedom of movement. ${ }^{43}$ The freedom of the individual is narrowly construed as connected with personal safety and the right not to be arbitrarily detained, and not as including wider freedoms of the person, such as the freedom to marry or the right of privacy.

Since the introduction of the référé procedure in 2000 , the administrative court has had a speedy method for handling complaints against unlawful administrative actions and issuing injunctions to make them stop. Even before these two decisions of the Tribunal des Conflits, the Conseil d'Etat had declared that the administrative court had jurisdiction to declare a voie de fait illegal and to grant a remedy against the administration. ${ }^{44}$ The Tribunal des Conflits in Panizzon specifically referred to this competence of the administrative courts in justifying the restriction of voie de fait and removing the doctrine of emprise from the range of matters which fell within the jurisdiction of the civil courts. Given these changes to the procedures before the administrative courts and the scope of the legal concept of voie de fait, jurisdiction in matters of the flagrant illegality of administrative decisions is likely in practice to lie with the administrative courts.

The distinction between a flagrant and an ordinary illegality was always going to be a fine one. A classic illustration is Carlier..$^{45}$ The claimant was a strong critic of the Administration of Fine Arts for its neglect of France's monuments. When photographing Chartres Cathedral, he was arrested on the order of the prefect and had his photographs confiscated. Soon afterwards, whilst queuing with tourists, he was refused entry to the belfry of the cathedral. The Conseil d'Etat held that his arrest was a flagrant illegality which was incapable of being connected to administrative functions, and so it constituted a voie de fait over which it had no jurisdiction. But the refusal of entry to the belfry was merely an unlawful way of performing the administrative task of giving users access to a public monument, and so that was an ordinary illegality for which the administrative courts were able to award compensation. In those situations where the vestiges of voie de fait remain, such subtle distinctions between degrees of illegality will stay relevant.

42 TC 9 June 1986, Commissaire de la République pour la région d'Alsace, no. 02434, RFDA 1987, 37 concl. M.-A. Latournerie.

43 TC 12 February 2018, Guyue c Agent judiciaire de l'Etat, no. C4110, Leb. 612.

44 CE 12 May 2010, Alberigo, no. 333565, Leb. 694; CE ord. 23 January 2013, Commune de Chirongui, no. 365362 , AJDA 2013, 788 .

45 CE Ass. 18 November 1949, no. 77441, S. 1950.3.49 note Drago. 


\subsection{PUBLIC PERSONS}

Public law can generally be considered to concern public persons. The Conseil constitutionnel decision of 1987 specifically mentions 'authorities exercising executive power, their agents, local authorities, or public bodies placed under their authority or control'. By this are clearly covered ministries and local authorities, as well as their executive agencies. But the category of public bodies is vaguer and there is also the question of whether private bodies are also included when they are running public services.

Organisations such as regulatory agencies are generally public bodies. As mentioned in Chapter 2, Section 4, many regulatory agencies are so-called independent administrative authorities (autorités administratives indépendantes (AAIs)) such as the CNIL. They are clearly governed by public law and challenges to their decisions are brought in the administrative courts. This was established in a very early case, Association syndicale du Canal de Grignac. ${ }^{6}$ Regulations approved by ministers obliged adjoining landowners to join a private association set up to maintain the Grignac Canal and its surroundings. Its creditors had to sue in the administrative courts. Some regulatory agencies are autorités publiques indépendantes (APIs), and they have legal personality. As mentioned in Section 2.5, legislation establishing such bodies regulating the commercial sector often stipulates that litigation against them is brought before civil courts.

Some publicly owned enterprises run public services in a commercial manner. While creation and control of the public service in question is a public law matter, the enterprise running the public service is governed by private law. This applies whether the enterprise in question is purely private in nature (a public limited company) or has the status of a public body, an entreprise public industriel et commercial (EPIC).

In La Bergamote, the Tribunal des Conflits made clear that the ordinary courts had jurisdiction over all matters concerning EPICs, 'except those relating to their activities which, such as regulation, policing and monitoring, belong by their nature to the prerogatives of public power. ${ }^{37}$ In that case, a bridge over a canal connecting the Marne and the Rhine at Nancy was under the control of an EPIC created by a law, Voies Navigables de France. It collapsed and blocked the river. As a result, a floating restaurant and cruise ship could no longer ply its trade. Its owners sued Voies Navigables de France

$4^{6} \quad$ TC 9 December 1899, no. o0515, S. 1900.3.49 note Hauriou.

47 TC 12 December 2005, EURL Croisières lorraines 'La Bergamote' c Voies Navigables de France, no $\mathrm{C}_{3455}$, Leb. 671. 
for compensation in the administrative courts. Because the maintenance of the bridge was not an exercise of public power, the Tribunal des Conflits upheld the view of the tribunal administratif that it did not have jurisdiction to deal with the claim.

Private bodies may still be governed for part of their activities by public law and thus come within the jurisdiction of the administrative courts. It was clearly established in Aide et Protection in $1938^{48}$ that 'a body charged with the performance of a public service, even if this body has the character of a "private enterprise", can still be governed by public law. That case concerned the caisses (funds) set up under the legislation establishing schemes for compensation for industrial injuries in both public and private employment. These bodies were private. The litigation concerned whether their employees were governed by rules prohibiting the accumulation of pensions and remuneration from different sources. Given that the provision of social insurance was a public service, it was legitimate to include the employees of these caisses in the ban on additional sources of income.

Whether a private body is performing a public service depends on an interpretation of the whole context of its activity. Three criteria are of particular relevance as set out in the Narcy decision: ${ }^{49}$ whether a public service mission has been conferred on the body; whether the body is given the exercise of public power to achieve this mission; and the control exercised over the body by the administration. In relation to the first, the conferral of a public service mission can be express or implied. The Aide et Protection case is a good example of an express legislative mission. But this can be implied from the other two features. Prerogatives of public power could involve the power to impose requirements on those who use a service, or to impose an obligation to belong to an association or to pay a contribution, or to enjoy a monopoly over an activity. In Montpeurt, litigation by a manufacturer against a wartime organisation set up to manage the use of resources in the glass industry was held to be within the jurisdiction of the administrative courts..$^{50}$ The organisation was performing a public service at a time of resource scarcity and challenges to its refusal to give a particular person the quota he desired were a public law matter. Many professional disciplinary bodies also have an ability to control membership and conduct. For example, in Bouguen, the claimant was able to challenge the refusal by the Conseil supérieur de l'ordre des

$4^{8}$ CE Ass. 13 May 1938, Caisse primaire 'Aide et Protection', no. 57302, D. 1939.3 .65 concl. Latournerie, note Pépy.

49 CE Sect. 28 June 1963, Narcy, no. 72002, Leb. 401.

50 CE Ass. 31 July 1942, Montpeurt, no. 71398, D. 1942, 138 concl. Ségalat. 
medecins, a private body governing the medical profession, to allow him to open a practice before the Conseil d'Etat. ${ }^{11}$ As will be seen, the cases on national professional sporting bodies also show how these perform a public service in regulating their sports and athletes.

Even without a clear legal basis to establish that a private body is performing a mission of public service, its organisation and activities may, taken together, suggest that it is engaged in such a mission, and thus its activities are within the jurisdiction of the administrative courts. In Ville de Melun, a private law association was created by the council to support cultural and leisure facilities in the town..$^{22}$ It received half of its money from the council and the rest from private sources, and it spent most of its money on activities within the town. The mayor was its ex officio president, and several councillors were on its committee. In the light of all these features, it was held to be performing a public service under the control of the council. Therefore, its accounts were public documents and the administrative courts had jurisdiction over litigation concerning them.

Professional bodies are typically private law institutions. They do perform regulatory functions and, in this work, they are considered to be performing a public service. This public service is underpinned by some form of ministerial or legislative authorisation. Under art. 131-8 of the Sporting Code, national sporting bodies are approved by a minister. Their statutes have to contain certain compulsory provisions and a disciplinary code which is consistent with a standard form. As a result, such professional sporting bodies are governed by public law in performing their specially authorised functions. For example, in Peschaud, the suspension of the vice president of the French football association pending a disciplinary inquiry was held to be within the jurisdiction of the administrative courts. ${ }^{53}$ The situation is different if the body is simply 'agrée', but does not hold any legal monopoly to run a given sport, as was the case with the aerobic and stretching federation. In that case, a disciplinary measure was the normal business of the association and the case belonged in the civil courts. ${ }^{54}$

51 CE Ass. 2 April 1943, no. 72210, S. 1944.3.1 concl. Lagrange, note Mestre.

52 CE 20 July 1990, Ville de Melun et Association 'Melun-culture-loisirs' c Vivien, nos. 69867, 72160, AJDA 1990, 320. See also CE Sect. 6 April 2007, Commune d'Aix-en-Provence, no. 284736 , RFDA 2007,812 : the association organising an international music festival was undertaking a mission of public service.

53 TC 7 July 1980, Peschaud c Groupement du Football professionnel, no. o2165, RDP 1981, 483 concl. Galabert.

54 CE 19 December 1988, Pascau, no. 79962. 
An industrial or commercial public service established as a private company, as opposed to an EPIC, may take administrative decisions. This was established in Air France c Barbier. ${ }^{55}$ The case concerned staff regulations under which air hostesses who got married were required to leave the service. Although Air France was a private company, its organisation was subject to ministerial regulation under legislation and its terms of employment were not governed by collective agreements with unions. In those circumstances, the administrative law courts were judged to have jurisdiction to deal with this issue as it relates to the assessment of legality of an administrative regulation of a public service.

\subsection{GENERAL CRITERIA FOR IDENTIFYING PUBLIC LAW MATTERS}

The account just given of the way the jurisdiction of public and private law courts is differentiated involves complex and subtle distinctions. There is no schematic framework, but a large number of specific decisions made by legislators and the courts during the past two hundred years. Authors have tried to make sense of this picture. Many have tried to distil organising principles to provide a sense of direction.

Laferrière sought the organising principle in the idea of 'public power'. In his view, the exercise of public power was administrative by nature and fell within the jurisdiction of the administrative courts. ${ }^{56}$ These were acts of authority and this conception was endorsed by Dean Hauriou, as seen earlier. In addition, their jurisdiction included the administration of public services (actes de gestion) as attributed by legislation. Dean Vedel, who was the reporter judge in the 1987 decision, also found public power (la puissance publique) to be the most useful guiding idea in the allocation of jurisdiction between the public and private law courts. ${ }^{57}$ This idea does find its way into the Conseil constitutionnel decision of 1987. But the administration does not always use its unilateral authority in order to achieve its purposes. The illustrations in the previous sections of this chapter also show the use of contracts, of funding and of influence. The exercise of public power is but one aspect of government and administration.

TC 15 January 1968, Compagnie Air France c Barbier, no. o1908, Leb. 789 concl. Kahn. The specific case law no longer applies because Air France was moved to the private sector in 2004. See Laferrière, Traité de la juridiction administrative, pp. 5-8.

57 See G. Vedel, Droit administratif, 7th ed. (Paris: Presses Universitaires de France, 1981), preface. 
Other writers, notably leading members of the Conseil d'Etat who taught at Sciences-Politiques in Paris Odent and Braibant,,$^{58}$ drew on the ideas in the earliest case law, such as Blanco, and considered that the performance of a 'public service' provided a key criterion in line of what Dean Duguit had previously said. ${ }^{59}$ When running a tobacco factory, the state was not exercising power or authority, but it was merely operating what it considered to be a public service. The same can be said for activities of education, health, roads, canals, transport and the many other things the modern state undertakes. The idea of public service captures the basic ethic around which public law activity operates.

The concept of 'public service' is, however, elusive. A public service exists where there is a public need, carried on under the aegis of a public authority. Such a 'public need' arises when it is identified by a public authority. Not all public needs are defined as such under legislation, as is the case of education or health care. A classic example is Terrier. ${ }^{60}$ The conseil départemental decided to rid its area of vermin. It offered a quarter of a franc for every viper killed by members of the public. The campaign was so successful that the fund set aside for these payments was exhausted and the conseil refused to pay the claimants for the vipers they had killed. The claimants brought an action in the local conseil de préfecture, which disclaimed jurisdiction. The Conseil d'Etat, however, found that this was a legitimate action to bring in the administrative courts, even though it was implicitly a contract claim. As has been noted in particular in Section 4 of this chapter, the identification of an activity as a public service has been important in giving jurisdiction to the administrative courts over private activities, such as, in Ville de Melun, supporting leisure and cultural activities, which in no way demonstrate the exercise of public power. ${ }^{61}$

The case of Ville de Melun illustrates the problem of the second criterion for a public service - that it is conducted under the aegis of a public body. Section 4 has already shown the wide variety of private bodies considered to be delivering public services and thus come within the scope of public law. Many these days are private companies, including major utilities such as electricity, gas and rail services. The special involvement of a public authority is not just in exercising command and direction, but also in exercising influence in

58 R. Odent, Cours de contentieux administratif (Paris: Les Cours de droit, 1965-6), p. 288 (the author maintained his approach in his last edition of 1977, p. 482); G. Braibant and B. Stirn, Le droit administratif français, $4^{\text {th }}$ ed. (Paris: Economica, 1997), p. 135.

59 See note 41.

6o CE 6 February 1903, Terrier, no. 07496 , Leb. 94, D. 1904.3.65 concl. Romieu.

61 $\quad$ See note 56. 
a privileged way, for example in giving a special status to a professional or sporting body and how it is required to operate. On the whole, these special relationships of public law apply to dealings between the public authority and the operator of the service, whereas the dealings between the provider and users of the service are within the jurisdiction of the ordinary courts. But if this triangle of relationships may be fairly clear, the jurisdiction over relationships with third parties is less clear. For example, where Gaz de France (then a public enterprise) caused poisoning by fumes, the client had to sue in private law courts (because he had a contract with the company), but the neighbour had to sue in public law courts for harm caused by a public work. ${ }^{62}$

The distinctive French conception of public service has come under increasing pressure within the EU. The Treaty of Maastricht included public activities within competition rules and, despite French lobbying, did not recognise 'public services' as an exception. Article 106(2) of the Treaty on the Functioning of the European Union (TFEU) now only makes special provision for 'services of general economic interest', which is a narrower concept. European Union directives on rail transport and the postal service, in particular, have had significant effects on how these services are organised in France. This has important implications for how far the very broad concept of public service with its special powers and protection can be maintained, particularly in the face of the requirement to open the market to providers lawfully established in other Member States. ${ }^{6}$

Even if neither of these classic criteria is fully satisfactory, that does not justify a descent into existentialism, even if some contemporary authors describe the situation as 'a mosaic of judicial solutions' ${ }^{64}$ The solutions adopted are not random, but there is no simple pattern. Rather there is a bundle of indicia, reflecting the variety of considerations which have to be borne in mind, of which the exercise of public power and the provision of a public service are two dominant features. Increasingly, the recent trend of legislation and judicial decisions in all the courts has been to focus on the expertise of specific courts in the matters under dispute and to ensure that the procedures adopted enable the most expert judges to rule on the issues.

62 TC 1 July 2002, Labrousse c Gaz de France, no. 03289, AJDA 2002, 689.

63 See for example J. Bell, "The Concept of Public Service under Threat from Europe? An Illustration from Energy Law' (1999) 5 European Public Law 189.

64 Lombard, Dumont and Sirinelli, Contentieux administratif, no. 634 with an echo to B. Chenot, 'L'existentialisme et le droit' (1953) Revue française de science politique at p. 57. 


\subsection{MECHANISMS FOR HANDLING CONFLICTS OVER JURISDICTION}

Conflicts between the ordinary and the administrative courts arise occasionally. In 1872, the Tribunal des Conflits was established to resolve them, a task previously given to the Conseil d'Etat itself (and for this very reason the judges of Tribunal des Conflits still meet in the Palais-Royal). The institution revived a short-lived body which existed during the Second Republic. It has the role of deciding issues of jurisdiction but may (on rare occasions) decide the substance of a case.

The membership of the Tribunal des Conflits was modified by the Law of ${ }_{17}$ February 2015. It currently is composed of four members appointed by the Conseil d'Etat and four members by the Cour de cassation, all appointed for a three-year term, renewable once. Each court also appoints two supplementary members for a similar period. The Tribunal des Conflits is presided over by one of its members chosen by the others. There is an understanding that the presidency will rotate between the members from the Conseil d'Etat and the members from the Cour de cassation. In the case of a tied vote, the 2015 law makes provision for a rediscussion of the case before an enlarged panel. In this case, the two supplementary members chosen by each court join the original members and it is hoped this will enable a decision to be reached. Until 2015, the Minister of Justice had the casting vote in the case of a tie. But this was considered incompatible with judicial independence. In practice, such tied votes are rare. Most estimates suggest that there were no more than a dozen such cases between 1872 and 2015. The last tied vote was in 1997 in Préfet de police de Paris. ${ }^{65}$ As in the Conseil d'Etat, the procedure is essentially written, which makes it possible to reassemble the panel with additional members without having to rehear the submissions of the parties. There are four forms of process by which conflicts can be raised.

\subsubsection{Positive Conflict}

A positive conflict arises when the ordinary courts hear a case which the administration considers should be heard by the administrative courts. In this case, the local prefect may raise an objection, a déclinatoire de compétence, setting out the reasons why the ordinary court does not have jurisdiction. The ordinary court then decides whether it has jurisdiction. It can either decline its jurisdiction or continue to assert it. In the latter case, it suspends hearing the

65 See note 16. 
case to give the prefect time to decide whether to abandon the objection or to refer the case to the Tribunal des Conflits. After the decision of the Tribunal, the case may either be allowed to continue before the ordinary courts or must be terminated and a new case started before the administrative courts.

As was shown in Radiodiffusion Française, the prefect may use this procedure to argue that neither court has jurisdiction. ${ }^{66}$ In this case, the prefect successfully claimed that the jamming of Radio Andorra by Radiodiffusion Française on the orders of a minister was an acte de gouvernement over which neither body of courts had jurisdiction.

There is no equivalent procedure whereby a litigant can object to the administrative court has entertained a case. In this case, all the litigant can do is to appeal the eventual decision on the ground that the lower court was not competent to hear the case. Only ministers before the Conseil d'Etat could decide to seise the Tribunal des conflits if the latter confirmed its jurisdiction, but it never happened, so this right was abolished in 2015 .

\subsubsection{Negative Conflict}

A negative conflict arises when neither an ordinary court nor an administrative court considers itself to have jurisdiction to hear a claim. There is obviously a risk of a denial of justice in this case. In order to speed up the handling of such cases, a decree of 25 July 1960 established a procedure of reference by which the rule is that the second court seised which also thinks it is not competent must seise the Tribunal des conflits before judging it is not competent in order to avoid the first court declining jurisdiction to an appropriate court in the other judicial order. Despite this, examples can be found where the resolution of the question about which court system has jurisdiction takes a significant number of years. ${ }^{67}$

\subsubsection{Preliminary Reference by a Court}

The decree of 1960 permitted the Cour de cassation or the Conseil d'Etat to request a preliminary ruling from the Tribunal des Conflits where there is a seriously difficult question of jurisdiction that involves the separation of ordinary and administrative courts. Such references are not frequent, but

66 TC 2 February 1950, no. 01243 , Leb. 652.

67 Lombard, Dumont and Sirinelli, Contentieux administratif, no. 673 cites the case of TC 20 October 1997, Paris Racing I c Fédération française de football, no. 03074, where a claim in relation to the payment on the transfer of a footballer took eight years between the TGI Paris declining competence and the TC coming to a decision on which court had jurisdiction! 
average at more than one a year. Article 35 of the decree of 27 February 2015 extended this possibility to any court where the solution to the case depends on such a question of jurisdiction. This process does make a serious attempt to speed up the decision on competence, because it does not require a final decision in the case. As noted in Section 1.2.1, art. 49 of the Code of Civil Procedure and art. R771-2 CJA implement this reference process.

\subsubsection{Conflict of Decisions}

As a result of the Law of 20 April 1932, it is possible to submit final judgments of administrative and ordinary courts to the Tribunal des Conflits in 'litigation having the same subject matter' (des litiges portant sur le même objet) and these are contradictory, thereby constituting a denial of justice. This arose as a result of litigation on a vehicle accident in which the claimant was a passenger. ${ }^{68} \mathrm{He}$ sued the driver of the private car in which he was travelling, and the ordinary court found him not liable. He sued the state for the driving of the other vehicle in the accident, an army truck, and the administrative court held that driver was not at fault. The Law of 1932 allows the Tribunal des Conflits to resolve the case itself. Such cases are rare because they require the identity of the subject matter and decisions by each court system. It has been invoked in only about ten cases since it was enacted. ${ }^{69}$ The Tribunal des Conflits has interpreted the rules more liberally in recent years to include not only where there are two final decisions, but also where one court has declined jurisdiction and a court from the other system has handed down a judgment, leading to a denial of justice. ${ }^{70}$

\subsection{CONCLUSION}

The division of jurisdiction between administrative and ordinary courts is an integral feature of the French conception of justice. The rationale for the system has evolved over time and the operational details have also changed. This way of delivering justice inevitably throws up difficult cases, but the remarkable thing is that there are so few. The Tribunal des Conflits handed down 24 decisions in 2019 , this contrasts with 2.25 million cases before the civil courts and more than 250,000 decisions handed down by the tribunaux administratifs. Difficulties in deciding on the appropriate court are rare.

69 Lombard, Dumont and Sirinelli, Contentieux administratif, no. 675.

70 TC 6 July 2009, Mario Bonato c APELIOR, no. C3692, RFDA 2009, 1229. 
Although the criteria for determining which is the appropriate court may be difficult to state succinctly, French lawyers basically know how they work. If we seek an explanation of the current rationale, it seems to lie in the expertise of the different courts. Just as lawyers are used to the special expertise of the CJEU and of the European Court of Human Rights, so lawyers are used to the special areas of expertise of administrative and ordinary courts. As far as the administrative courts are concerned, it is their knowledge not just of administrative law, but also of how the administration works. On the other hand, the ordinary courts are better placed in commercial matters and dealing with criminal matters. The Constitution now provides the basic framework within which the questions of jurisdiction between the administrative and ordinary courts is decided by the legislator, but the case law decides on its own criteria when the legislator has not taken a view on a particular litigation. This adds a layer of principle to what might otherwise appear to be pragmatic solutions to particular problems. 